\title{
Scientific integrity tested by the Covid-19 pandemic
}

\author{
AMAR JESANI
}

In October 2020, the world's three top medical journals, The Lancet, The New England Journal of Medicine and Nature denounced, in their editorials, the United States' response to the Covid-19 pandemic, and appealed to US citizens to vote for change (1-3). Nature went to the extent of naming the candidate to vote for. The Lancet has a history of making comments and taking positions on political issues. However, what surprised many was the NEJM editorial, signed by several of its editors, taking a partisan political position for the first time since it was established in 1812, 208 years ago (4). These editorials express not only disappointment with the political leadership, but anger against its wilful disregard of science, undermining of services in the public sector and regulatory institutions, gross partisan political interference in science, and so on.

In traditional public health, since the time of Rudolf Virchow in the $19^{\text {th }}$ century, politics was regarded as medicine on a grand scale. This position of public health is often juxtaposed with science-centric, apparently apolitical clinical medicine. Clearly, the Covid pandemic has helped in bridging the gap because none can now afford to be apolitical. The explicit recognition of the role of politics by medicine and science, is therefore, welcome.

At the same time, it may also be noted that while editors of these prestigious journals have taken political positions, the international and national associations and committees of medical journal editors have so far not stuck their necks out by taking positions on the handling of the pandemic and interference in scientific processes by the political leadership. In India, no medical journal or association of medical journal editors has taken a strong critical position on the government's handling of either of these issues. It is not clear to what extent this silence is due to a fear of reprisals, or to the belief that medical journals should stay "apolitical" - though to be apolitical is also a political position, sometimes equated with collusion and silent support. So there is a long way to go before medicine and science push back the intrusion of irrationality and untruth brought about by certain types of politics.

\section{Politics devoid of science}

The Covid pandemic has made almost everybody of some prominence claim expertise in health issues. And this is not about the commonplace wisdom expressed by some individuals, but about people entrusted with policy making and various types of professionals who appropriate the role of experts. Thus, this pandemic was accompanied by an infodemic with multiple facets, often spearheaded by people who had hitherto done no work in public health and epidemiology.

When faced with a completely new pandemic, we need to be very humble in acknowledging our lack of definitive knowledge about it. We have to intervene, of course, based on incomplete information, but at the same time learn continuously as evidence accumulates, and some critical learning comes from the mistakes made. The acknowledgment of failures, measures taken for course correction etc, are inseparable parts of scientific practice.

However, the politicians and political ideologues everywhere did not have the patience to provide such space to science. Many simply panicked, many wanted quick fixes. Many just denied the pandemic and the simplest measures of physical distancing and use of masks. In short, in many countries, politics was more interested in protecting the power it held rather than science and the people's safety.

Author: Amar Jesani (amarjesani@gmail.com), Independent Consultant Researcher and Teacher in Bioethics and Public Health, 31, Swatantrya Sainik Nagar, Amboli, Andheri West, Mumbai 400058 INDIA.

To cite: Jesani A. Scientific integrity tested by the Covid-19 pandemic. Indian J Med Ethics. 2020 Oct-Dec; 5(4) NS: 261-3. DOI:10.20529/JJME.2020.115.

○ Indian Journal of Medical Ethics 2020 
Our story is no different. In India, over the years, the state and politicians have given the least importance to health issues, with state expenditure on health stagnating for decades at around 1\% of the GDP. Public health infrastructure and human resources have been grossly neglected. So in March 2020, India was the least prepared to meet the challenges posed by Covid-19. The pandemic should have been treated as a wakeup call to build a resilient public health system as was explained in an editorial in IJME in April (5).

India's first organised response to the pandemic, which was just entering the country with not many cases in mid-March, was to impose, with a notice of only four hours, a repressive prolonged lockdown on the whole country. Unmindful of any scientific evidence, claims of overcoming the pandemic in 21 days were made - claims that easily led to complacency in caring for the poor and the homeless, causing unemployment on a massive scale, forcing people to walk thousands of kilometres to go back to their native villages. The democracy was transformed into a police state to discipline people looking for food and basic necessities, and massive prejudicial campaigns were allowed to be carried out against the minorities, to punish them as "infection spreaders". Indeed, the extent to which public health as a discipline and an authority identified itself with such aspects of the lockdown, stripped it of its human face and made it an instrument of heartless political power.

The response of the healthcare system dominated by the private sector and the market, to patients in urgent need of medical care is another story, to be narrated some other time. Suffice it to say that the very reason to impose the lockdown - to slow down the spread of infection, to strengthen the healthcare system, to attend to people needing medical care - has not happened, after more than six months. The urban and rural public healthcare system, which should have received massive investment in this pandemic, still remains as deprived of resources, and the state did not make any attempt to temporarily take over the private system to ensure universal free care for all Covid patients, irrespective of their social backgrounds.

Indeed, healthcare did get politicised, but political ideology dictated the actions of the state and politicians, not the science of public health.

Many public health professionals and some activists had thought that, despite the ideological fetters restraining the state in India, the traumatic experience of the pandemic would awaken some humanity in the policy makers to re-vitalise the public health system.

\section{Politics in science}

Traditionally, institutional public health has maintained proximity to the state and politics as large population-based public health programmes need state support to succeed. Public health practitioners often take pride in guiding the state in using science for the people's welfare. In the future, we hope they will discuss how the state took over control and dictated terms on this public health crisis.

How have science and scientific research fared in such an environment dominated by partisan politics? The IJME editorial in the July-September 2020 issue documented in detail the manner in which repurposed drugs were provided approval for treatment without any robust scientific evidence (6). Not only did the Indian Council of Medical Research (ICMR), and the drugs regulator dilute established scientific standards, they actively promoted drugs with dubious evidence. All such steps were taken under a highly opaque regulatory system. While the pandemic is considered a threat to humanity, the regulators do not consider it important to make public the scientific criteria used by them to approve experiments (clinical trials) and the ultimate use of medical technology to combat infection and its consequences.

In this context, it is important to mention one instance which brought out both political interference in science as well as in medical publishing.

One of the methods used to understand the spread of infection in the population is to do serological surveys to estimate the numbers of people with antibodies against the virus. The ICMR and other institutions thus undertook massive sero-surveillance, which was supposed to feed the policy makers with clues to design or change their strategies to combat the pandemic. For that, the findings of such a survey need to be brought out at the earliest. However, the findings of the survey done in April-May 2020 were made publicly available only in September in the July-August issue of the Indian Journal of Medical Research (IJMR) (7). And as it was revealed soon after the publication, the delay was caused by the government's discomfort with the findings.

On publication of the survey findings, four of the 74 authors anonymously, and three on record, told the media that the ICMR, which is the publisher of the journal, had instructed them to leave out the infection prevalence data of the containment zones or hotspots of ten cities (8). Apparently, such instructions were conveyed to the authors by email by the Director General of ICMR, who is also one of the co-authors of the paper. Clearly, the chief of the top medical research body not only took orders from the political class but used his clout as publisher of the journal to force other authors to comply with the order. What marks this surrender as more important is that those in power did not make any effort to show that such censorship of science was done for the public good. The only hypothesis one can advance is that this abhorrent exercise was conducted so that the state can 
continue to deny that there was community transmission and that severe containment measures like the lockdown, declared to be successful, were actually not so successful in arresting the spread of the infection.

As compared to the audacity of the editors of three western medical journals to speak truth to power as mentioned in the opening paragraph of this editorial, the top medical journal of India succumbed to political pressure. The worst part, as far as we know, not mentioned anywhere, is that in this episode nobody even inquired what the position of the editor of the IJMR was on this issue. The editor, on her part, did not speak to the media or offer any clarification. This abdication of editorial responsibility in favour of the head of the public institution as publisher seems to be complete.

\section{References}

1. Editorial, The US election 2020. Lancet.2020 Oct;396(10260):1373.DOI:10.1016/S0140-6736(20)32260-1

2. The Editors. Dying in a leadership vacuum. New Engl J Med. 2020 Oct; 383:1479-80. DOI: 10.1056/NEJMe2029812.

3. Editorial, Why Nature supports Joe Biden for US president, Nature. 2020 Oct; 586(7829):335. Doi: 10.1038/d41586-020-02852-x.

4. Kolata G. In a first, New England Journal of Medicine Joins Never-Trumpers. New York Times.com 2020 Oct 7[cited 2020 Nov 2]. Available from: https:// www.nytimes.com/2020/10/07/health/new-england-journal-trump.html

5. Gopichandran V, Subramaniam S. Response to Covid-19: An ethical imperative to build a resilient health system in India. Indian J Med Ethics. 2020 AprJun; 5(2) NS: 89-92. DOI:10.20529/IJME.2020.026.

6. Rathi S, Kalantri SP. Ethics of clinical research and practice in India during the Covid-19 pandemic. Indian J Med Ethics. 2020 Jul-Sep; 5(3) NS: 175-80 DOI: 10.20529/IJME.2020.080.

7. Murhekar MV, Bhatnagar T, Selvaraju S, Rade K, Saravanakumar V, Thangaraj JWV, et al. Prevalence of SARS-CoV-2 infection in India: Findings from the national serosurvey May-June 2020. Indian J Med Res. 2020 Jul \& Aug;152(1\&2):48-60. DOI: 10.4103/ijmr.IJMR_3290_20.

8. Mudur GS. How Covid numbers were hushed up. Telegraphindia.com. 2020 Sep 20 [cited 2020 Nov 2]. Available from: https://www.telegraphindia.com/ india/how-covid-numbers-were-hushed-up/cid/1792482\#.X2bZ7twuLQY.whatsapp

\section{APPEAL FOR DONATIONS TO THE FORUM FOR MEDICAL ETHICS SOCIETY}

The Forum for Medical Ethics Society (FMES), publisher of the Indian Journal of Medical Ethics (IJME), appeals to subscribers, contributors, readers, supporters and well-wishers of IJME and FMES to donate to its corpus and towards the publication of IJME. Contributions from both individuals and institutions are welcome.

FMES has published the journal on a shoestring budget, without a break, since 1993. The journal is known for being open access and spearheading discourse aimed at advancing social justice in health and ethics-centred healthcare and health research reform. It is recognised widely as an authoritative resource of knowledge in bioethics and allied areas of enquiry. FMES and IJME have not only sustained themselves but have grown over these past 25 years. Our ever-growing base of readers, contributors, and reviewers enables the publication of multiple and diverse perspectives on wide-ranging topical areas. We have also striven to upgrade the journal technically to keep up with the advances in publishing to widen our reach. This has been possible only because of your steadfast and sustained support.

We are committed to maintaining our editorial independence which is critical to safeguarding the scientific integrity of what we publish. Therefore, wider support from all those who are committed to social justice in health is essential.

FMES is registered under the Societies Registration Act, 1860 (Reg No: Mumbai-218-1995-G.B.B.D.D) and the Bombay Public Trusts Act, 1950 (Reg No: F-17441 Mumbai, 1995), and donations are eligible for tax exemption under Section 80G of the Income Tax Act, 1961

For more details on how to support us, write to admin@ijme.in or visit our website www.ijme.in/subscribe-support/

\section{SUPPORT OPEN-ACCESS ACADEMIC PUBLICATIONS, DONATE TO THE FMES CORPUS FOR THE PUBLICATION OF IJME!}

